\title{
CORRELATION OF NEIGHBORHOOD RELATIONSHIPS, CARBON ASSIMILATION, AND WATER STATUS OF SAGEBRUSH SEEDLINGS ESTABLISHING AFTER FIRE
}

\author{
Katherine DiCristina ${ }^{1}$ and Matthew Germino ${ }^{1,2}$
}

\begin{abstract}
Interactions of Artemisia tridentata ssp. vaseyana (mountain big sagebrush) and neighboring herbs may affect community development following fire in sagebrush steppe. Dry mass, photosynthesis, and water relations were measured for seedlings of A. tridentata ssp. vaseyana occurring at different distances from neighboring herbs in the initial growing seasons following fire, when herbs dominate plant community cover. Seedling mass significantly increased as distance to neighboring herbs increased, although a low $r^{2}$ indicated that mass was also affected by other sources of variation. Carbon assimilation $\left(A_{n e t}\right)$ was also greater for A. tridentata ssp. vaseyana seedlings in microsites farther from herbs, except during those sampling dates when $A_{n e t}$ and water availability were at low levels. Contrary to our expectations, water status of seedlings was not correlated with their distances to neighboring herbs, and supplemental watering did not affect the slope of the relationship between seedling mass and distance to neighboring herbs. These findings suggest that negative relationships between A. tridentata ssp. vaseyana seedlings and herbs establishing after fire are not likely due to competition over water and may instead result from interactions over factors not measured here (e.g., nutrients).
\end{abstract}

Key words: sagebrush, seedling establishment, photosynthesis, plant-soil-water relations, fire, Artemisia tridentata ssp. vaseyana.

Management of fire regimes, including prescribed burning and fire suppression, is common in sagebrush steppe ecosystems. Fire is applied in sagebrush steppe to promote forage production, reduce fuel loads, or restore disturbance for wildlife habitat. Whether, and to what extent, application of fire achieves these ecological goals is currently debated. For example, there is considerable discrepancy in how sagebrush recovers following fire. Wambolt et al. (2001) reported much lower levels and higher variability of sagebrush (Artemisia tridentata) cover than expected based on previous studies (Harniss and Murray 1973) for sites burned up to 3 decades prior to their study. Lack of sagebrush recovery following fire is a major concern for sustainability of Greater Sage-Grouse (Centrocercus urophasianus) and other wildlife (Connelly et al. 2000). Altered rates of sagebrush reestablishment may result from changes in floristics of herb communities such as with exotic plant invasions (Brooks and Pyke 2001).

Resprouting and rapidly colonizing species (mostly herbs) tend to dominate burned sagebrush steppe in the decade following fire while the slower-growing shrub Artemisia tridentata reestablishes (Harniss and Murray 1973). Direct observations of interactions between sagebrush seedlings and other plant species are rare in the literature (e.g., Daubenmire 1975, Owens and Norton 1989, Schuman et al. 1998, Berlow et al. 2002), especially for post-fire conditions. Seed dispersal and germination have been studied for $A$. tridentata and other aridland shrubs in undisturbed and postfire situations (e.g., West and Hassan 1985, Young et al.1990, Tyler 1996, Chambers 2000), but less is known about factors affecting seedling success. New establishment of A. tridentata ssp. vaseyana seedlings was detected at sites burned 1-3 years prior to sampling and at sites in later stages of succession (i.e., having mature shrubs), but not at sites at intermediate stages of succession that had denser herb layers (DiCristina et al. in review, Cook and Lewis 1963, Harniss and Murray 1973, Young and Evans 1978). These temporal patterns of A. tridentata ssp. vaseyana establishment are nearly the opposite of typical changes in herb cover during disturbance-succession cycles (Harniss and Murray 1973) and

\footnotetext{
${ }^{1}$ Department of Biological Sciences, Idaho State University, Pocatello, ID 83209-8007.

${ }^{2}$ Corresponding author. E-mail: germmatt@isu.edu
} 
indicate a potentially negative effect of herbs on A. tridentata ssp. vaseyana reestablishment following fire.

The objective of this research was to determine how physiological performance of $A$. tridentata ssp. vaseyana seedlings is affected by their proximity to neighboring herbs following fire and within the natural range of neighborhood spacing. We hypothesized that seedlings in microsites closest to neighboring herbs would exhibit less dry mass accumulation and photosynthetic carbon uptake. Moreover, we predicted that reductions in seedling growth and photosynthesis near herbs would result from water limitations, and that seedlings would therefore express the most negative relationship to neighboring herbs after midsummer, when water availability reaches yearly minimums. Seedling mass was measured in response to experimental manipulations of distances to herbs, with and without supplemental water additions. We focused our sampling efforts on a site burned 1-2 years previously, when herbs dominated the plant community cover.

\section{Methods}

Research was conducted during the snowfree season of 2003 and 2004 at a site burned in September 2002 at the USDA, Agricultural Research Service, U.S. Sheep Experiment Station (USSES; $44^{\circ} 14^{\prime} 44^{\prime \prime} \mathrm{N}, 112^{\circ} 12^{\prime} 47^{\prime \prime} \mathrm{W} ; 1650$ $\mathrm{m}$ ASL), near Dubois, Idaho. The larger burn site was within an area $<2 \mathrm{~km}^{2}$ and consisted of more than 11 burn patches ranging in size up to 100 ha. All patches burned within about 24 hours of each other. Areas we sampled had blackened soil and few woody stems after the fire. The dominant shrub in this community was Artemisia tridentata ssp. vaseyana Nutt. Less abundant shrubs were Chrysothamnus viscidiflorus Nutt., Tetradymia canescens DC. and Purshia tridentata (Pursh) DC. Perennial bunchgrasses such as Agropyron dastychium (Hook.) Scribn., Festuca idahoensis Elmer, and Poa sandbergii Vasey were common, as were numerous short-lived perennials such as Achillea millefolium L., Antennaria sp. Gaertn., Erigeron spp. L., and Phlox spp. L. Post-fire ground cover on forty $1-\mathrm{m}^{2}$ plots in 2003 was $5 \%$ grass, $15 \%$ forb, and $35 \%$ soil, in addition to some litter and rock (DiCristina et al. in review). Cover for the same plots in 2004 was $26 \%$ grass, $29 \%$ forb, and $22 \%$ soil. Soils were fine, loamy, mixed, frigid Calcic Argixerolls derived from wind blown loess or residuum (Natural Resources Conservation Service 1995). Total annual precipitation averaged $297 \mathrm{~mm}$ over the last 78 years, with an average of 131 $\mathrm{mm}$ accumulating from May through August (Western Regional Climate Center, Desert Research Institute, Reno, NV). Precipitation from January through September was $140 \mathrm{~mm}$ in 2003 and $190 \mathrm{~mm}$ in 2004, compared to an average of $240 \mathrm{~mm}$ for these months over the previous 78 years. There has been light grazing $\left(21.3\right.$ sheep days $\left.\cdot \mathrm{ha}^{-1}\right)$ on the site from 1968 to 2002.

\section{Responses of Dry Mass to Experimental Manipulations}

In 2003 we examined seedling responses to manipulations of distance to neighboring herbs and water availability (+ or - supplemental water). The seedlings were those recently emerged (within a week or so) during the 1st growth season following the 2002 fire. We identified 5 replicate plots in the burn areas that were each about $6 \mathrm{~m}^{2}$ in areal extent and had at least 20 A. tridentata ssp. vaseyana seedlings. To generate a range of distances of seedlings to herbs in each plot, we removed varying amounts of herbs from A. tridentata ssp. vaseyana seedlings that had naturally established within $10 \mathrm{~cm}$ of herbs. Distances from the base of each A. tridentata ssp. vaseyana seedling were then measured to the base of the nearest herb in each of 4 quadrants around seedlings (NW, NE, SE, SW), for a total of 4 distances per seedling. The 4 distances were added together and are hereafter called the "sum distance" of each A. tridentata spp. vaseyana seedling to surrounding vegetation. Sum distance to nearest neighbor was chosen over other measures of neighborhood spacing, such as distance to nearest neighbor, because it provides representation of $>1$ neighbor, yet can be measured quickly enough in the field to allow sufficient replication. Moreover, sagebrush seedling measures were correlated more strongly to the sum distance to neighbors than to other calculations of neighborhood spacing. It is likely that herb species can differ in their relationship to sagebrush seedlings, as could be revealed if our data collections were replicated for separate species. We did not have sufficient replication to elucidate seedling relationships to different species of herbs. 
We removed surrounding herbs by clipping aboveground structures at least once every 2 weeks from July through October. We also randomly selected half of each replicate plot to receive supplemental watering. Water stored in 113-L cisterns was applied to the root zones of seedlings via drip irrigation lines on electric timers (Model 3020, Melnor USA). Seedlings in plots with supplemental water received about $300 \mathrm{~mL}$ of water in early morning and late evening, every day from July through September. We measured volumetric water content $\left(\mathrm{VWC}, \mathrm{m}^{3} \cdot \mathrm{m}^{-3}\right)$ of soils under all seedlings using a handheld time domain reflectometer unit (Model CS616, Campbell Scientific, Logan, UT) with $12-\mathrm{cm}$ probes. Soil texture and bulk density were similar among the sites (sandy loam; Germino and Seefeldt unpublished data). VWC was measured 4 times throughout the watering treatments: 1 August, 13 August, 3 September, and 3 October.

After September, all experimental seedlings were carefully excavated, rinsed in deionized water, and dried in an oven at $21^{\circ} \mathrm{C}$ for 24 hours. Seedling mass was then measured to $0.001 \mathrm{~g}$. There were 59 and 33 seedlings among the 5 replicate watered and unwatered plots, respectively. We used regression and 2-way ANOVA to test for differences in seedling mass with different sum distances to neighboring herbs with and without watering. Seedlings selected for this experiment were initially similar in height $(<2 \mathrm{~cm})$ and age (emerged within about 1 week of each other), and we assumed their masses at the beginning of the experiment were within $0.01 \mathrm{~g}$ and $0.05 \mathrm{~g}$ dry mass, based on height measurements and mass:height relationships (K. DiCristina unpublished data).

\section{Ecophysiological Responses to Neighboring Herbs}

Photosynthesis, water relations, and distance to neighboring herbs were measured in 2004 on seedlings of Artemisia tridentata ssp. vaseyana that we detected within 3 separate belt transects, each $5 \mathrm{~m}$ wide by $25 \mathrm{~m}$ long and positioned in one $\sim 100$-ha burn patch. Data were collected in 3 separate sampling periods in 2004: 24-25 June, 17-18 July, and 4-5 September. Thirty seedlings were harvested at each sampling date, requiring selection of 30 new seedlings for each subsequent sampling. Seedlings were in their 1st (or possi- bly 2 nd) season of growth and were between $1.5 \mathrm{~cm}$ and $10 \mathrm{~cm}$ (most were 4-7 cm) in height, with 7-20 leaves per plant.

Sum distance to neighboring herbs (see methods above), photosynthetic gas exchange, and water status were measured for each seedling. We measured net photosynthetic carbon assimilation $\left(A_{n e t}\right)$ and $g_{s}$ with a portable gas exchange system (LI-6400, LICOR Inc., Lincoln, NE) equipped with an artificial LED light source and $\mathrm{CO}_{2}$ controller. Relative humidity, temperature, and $\mathrm{CO}_{2}$ were maintained near ambient values during measurements. Measurements were made during midmorning to midday during the hours of maximal photosynthesis; no daily time effects were evident in our data. Light intensity was $1000 \mu \mathrm{mol}$. $\mathrm{m}^{-2} \mathrm{~s}^{-1}$ for all measurements. All values were reported as silhouette leaf area according to recommendations of Smith et al. (1991). We quantified silhouette leaf area of each seedling by taking a digital photo of leaf area, with the seedling naturally configured in the measurement chamber, perpendicular to the artificial light source, and next to objects of known size for calibration. Leaves and calibration objects in photos were traced onto paper and scanned into a computer-imaging program (Image J, version 1.23p) for calculation of leaf area.

Predawn xylem pressure potentials (PDXPP) and midday xylem pressure potentials (MDXPP) were measured in the field immediately after excising shoots at the root interface (Scholander-type pressure chamber, Model 1000, PMS Instrument Co., Corvallis, OR). We measured PDXPP between 0530 hours and 0630 hours on all sampling dates for half $(n=15)$ of each sample population, except in June, when we measured the entire sample population $(n=$ 30) before dawn. We measured MDXPP between 1130 hours and 1400 hours for half $(n=$ 15) of each sample population in July and September only.

Time domain reflectometer (TDR) probes and data loggers (models CS616 and CR10, respectively, Campbell Scientific, Logan, UT) were used to measure and record VWC at 1 central location in the burn area. VWC was recorded at 4-hour intervals from June through September on 2 sets of $30-\mathrm{cm}-$ long probes inserted horizontally at soil depths of $5 \mathrm{~cm}$ and $50 \mathrm{~cm}$. Soil water contents can vary considerably in space, and the TDR data were 


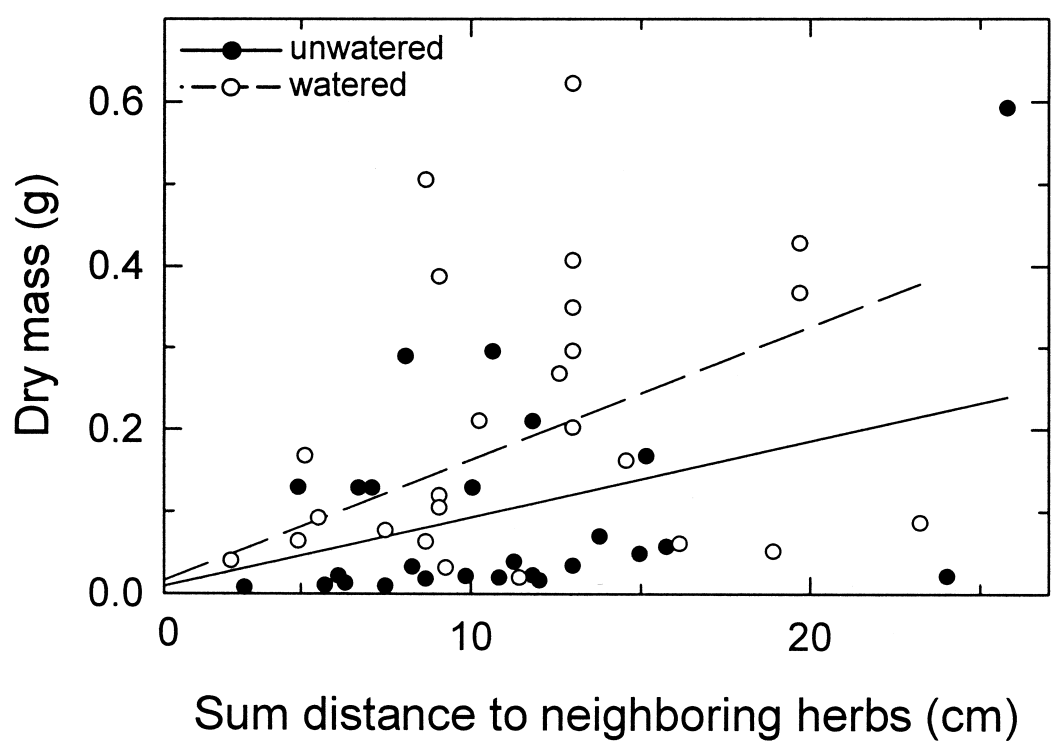

Fig. 1. Correlations of dry mass of Artemisia tridentata ssp. vaseyana seedlings and their sum distance to neighboring herbs in watered and unwatered plots in 2003. The coefficient of determination $\left(r^{2}\right)$ was $0.19(P=0.02)$ for unwatered seedlings (open symbols and dashed line) and $0.09(P=0.10)$ for watered seedlings (solid symbols and solid line). Dry mass was determined at the end of September, following 3 months of treatment application. Each point is a replicate seedling ( $n=27$ for watered plots, $n=27$ for unwatered plots).

therefore used only to estimate how the timing of our physiological measurements corresponded to general seasonal trends in drying or to summer rains that could potentially wet soils.

We used analysis of covariance (ANCOVA) to determine if month (main effect) affected the relationship between physiological responses of A. tridentata spp. vaseyana and distances to neighbors (covariate). PDXPP values were log-transformed for statistical analyses. Statistical differences among periodic measures of VWC (i.e., not the continuous data logger readings) between months were not tested due to low replication, and we report only means and standard deviations $(\bar{x} \pm s)$ for monthly values for each soil depth under the watered and control plots. Least-square regression analyses were used to characterize relationships between $A_{\text {net }}$ or $g_{s}$ and PDXPP over all sampling dates. Differences between specific means were tested with Tukey-Kramer tests and deemed significant when $P<0.05$. All analyses were conducted using SAS version 8 and JMP version 3.1 (SAS Institute, Inc., Cary, NC).

\section{Results}

Seedling mass was negatively correlated to proximity of neighboring herbs, though distances to herbs explained only a small amount of variation in seedling mass (slope $=0.001 \mathrm{~g}$. $\mathrm{cm}^{-1}, r^{2}=0.19, F_{1,26}=5.9, P<0.05$; Fig. 1$)$. Supplemental watering led to a more negative but less significant correlation of seedling mass and proximity to herbs (slope $=0.016 \mathrm{~g}$. $\mathrm{cm}^{-1}, r^{2}=0.09, F_{1,26}=3.0, P=0.10$; Fig. 1 , $P=0.05$ for differences in slope). Supplemental watering thus did not appear to ameliorate the negative relationship of seedling growth and proximity to herbs, even though watering increased the mean dry mass of seedlings considerably $\left(F_{1,53}=4.03, P<0.001\right)$.

On all dates measured, VWCs in plots with supplemental water were $8 \%-48 \%$ greater than in unwatered plots $\left(F_{1,335}=92.43, P<\right.$ $0.0001)$. Mean VWC values of unwatered plots for monthly sampling dates from June 2003 to September 2003 were $11.0 \pm 1.0,9.8 \pm 0.3$, $10.3 \pm 0.6$, and $13.9 \pm 0.4$; whereas mean VWC values of watered plots were $17.9 \pm 1.0,16.2 \pm$ $1.4,20.0 \pm 1.3$, and $15.1 \pm 0.5$, respectively. 


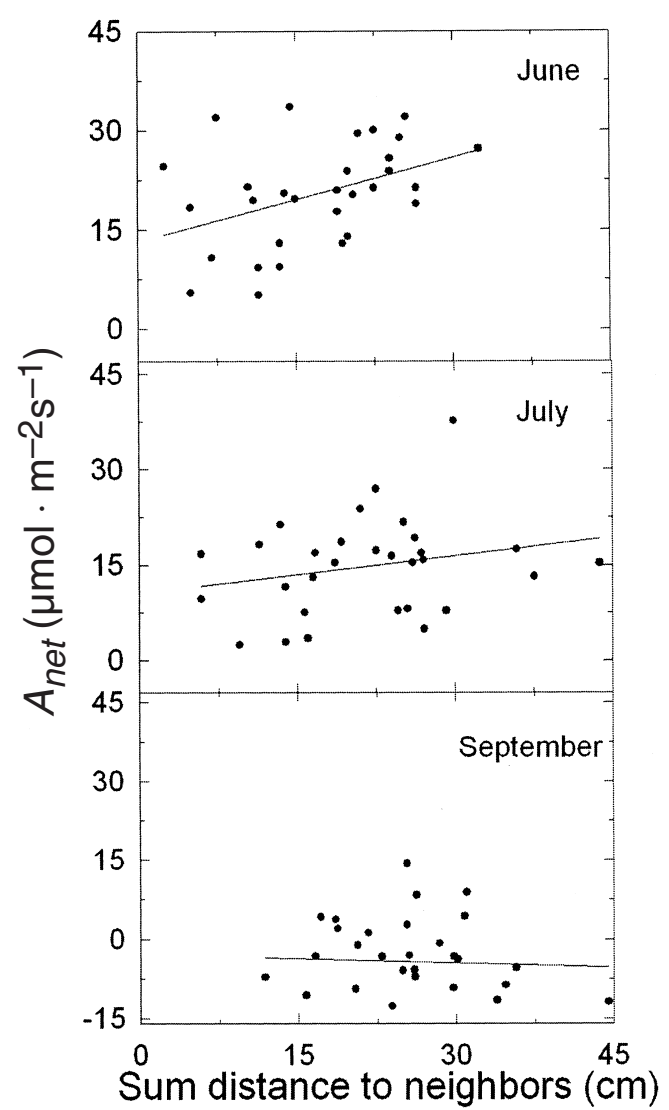

Fig. 2. Relationship of photosynthesis $\left(A_{\text {net }}\right)$ in Artemisia tridentata ssp. vaseyana seedlings to their sum distance to neighboring herbs in June, July, and September 2004. The correlation is significant only in June $\left(r^{2}=0.14, P=\right.$ $0.03)$. Each point is a replicate seedling $(n=28-30$ separate seedlings for each sampling date).

There was $\sim 13 \mathrm{~mm}$ of precipitation during the month of September, compared to a mean of $6.3 \mathrm{~mm}$ for each of the previous 3 months.

In June there was a positive relationship $\left(r^{2}\right.$ $=0.14, F_{1,29}=5.6, P=0.03$; Fig. 2 ) between net photosynthesis $\left(A_{n e t}\right)$ and distance from $A$. tridentata ssp. vaseyana seedlings to neighboring plants. We did not detect any significant effect of sum distance on $A_{n e t}$ in July or September (Fig. 2). The percent of A. tridentata ssp. vaseyana seedlings having sum distances to neighboring herbs of $\leq 12 \mathrm{~cm}$ was $33 \%$ in June, 10\% in July, and 0\% in September (Fig. 2). Mean sum distances from A. tridentata ssp. vasayana seedlings to surrounding herbs increased $\sim 35 \%$ from June to September $\left(F_{2,89}\right.$ $=8.7, P<0.001 ;$ Fig. 2). No correlations of

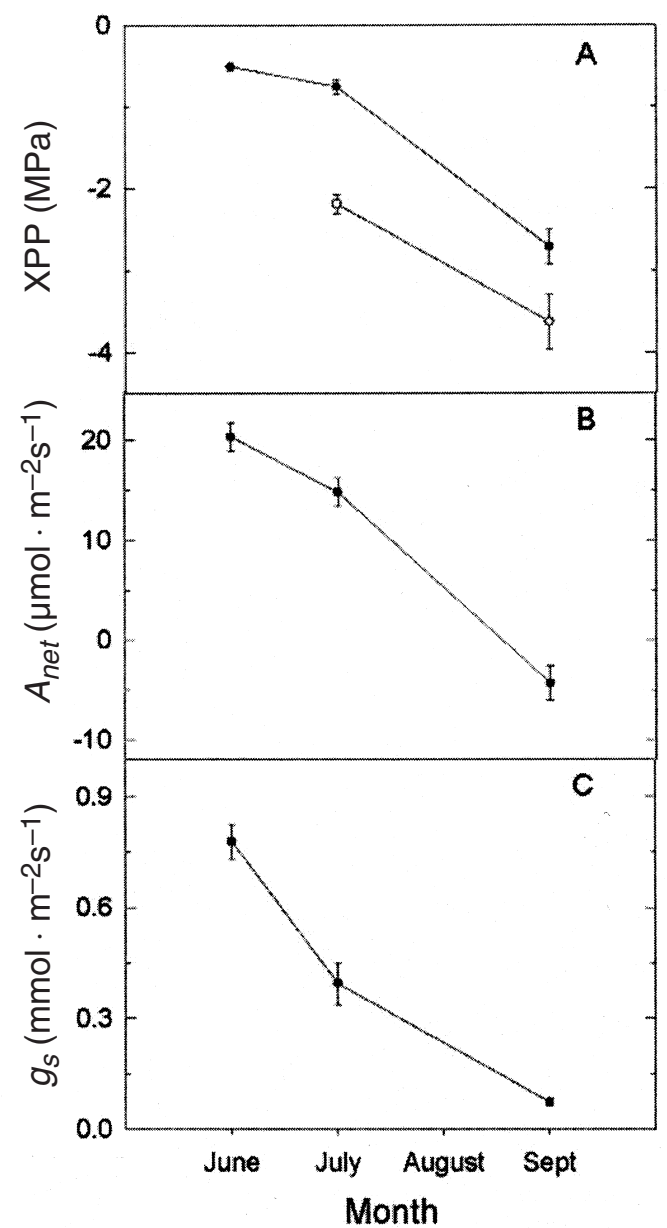

Fig. 3. (A) Xylem pressure potential (XPP), (B) photosynthesis $\left(A_{n e t}\right)$, and $(\mathrm{C})$ stomatal conductance $\left(g_{s}\right)$ of Artemisia tridentata ssp. vaseyana in each of 3 months sampled in 2004. In panel A, XPP is shown for measurements made both at predawn (solid circles) and midday (open circles). Bars represent $1 s_{\bar{x}}$ around the mean $(n=$ 15-30).

stomatal conductance $\left(g_{s}\right)$ or the xylem pressure potential measure of water status (XPP) and sum distances of seedlings to neighboring herbs were detected on any sampling dates (results not presented).

By September, $A_{\text {net }}\left(F_{2,89}=71.7, P<\right.$ $0.0001), g_{s}\left(F_{2,89}=60.0, P<0.0001\right)$, PDXPP $\left(F_{2,56}=112.7, P<0.0001\right)$, and MDXPP $\left(F_{1,20}=19.4, P<0.001\right)$ were considerably lower than measurements in June (Fig. 3). At 5 $\mathrm{cm}$ soil depth, VWC $\left(\mathrm{m}^{3} \mathrm{H}_{2} \mathrm{O} \cdot \mathrm{m}^{-3}\right.$, reported as a percentage) in 2004 was highest in June $(19.0 \% \pm 4.2 \%[s])$ but decreased to $15 \%$ on 


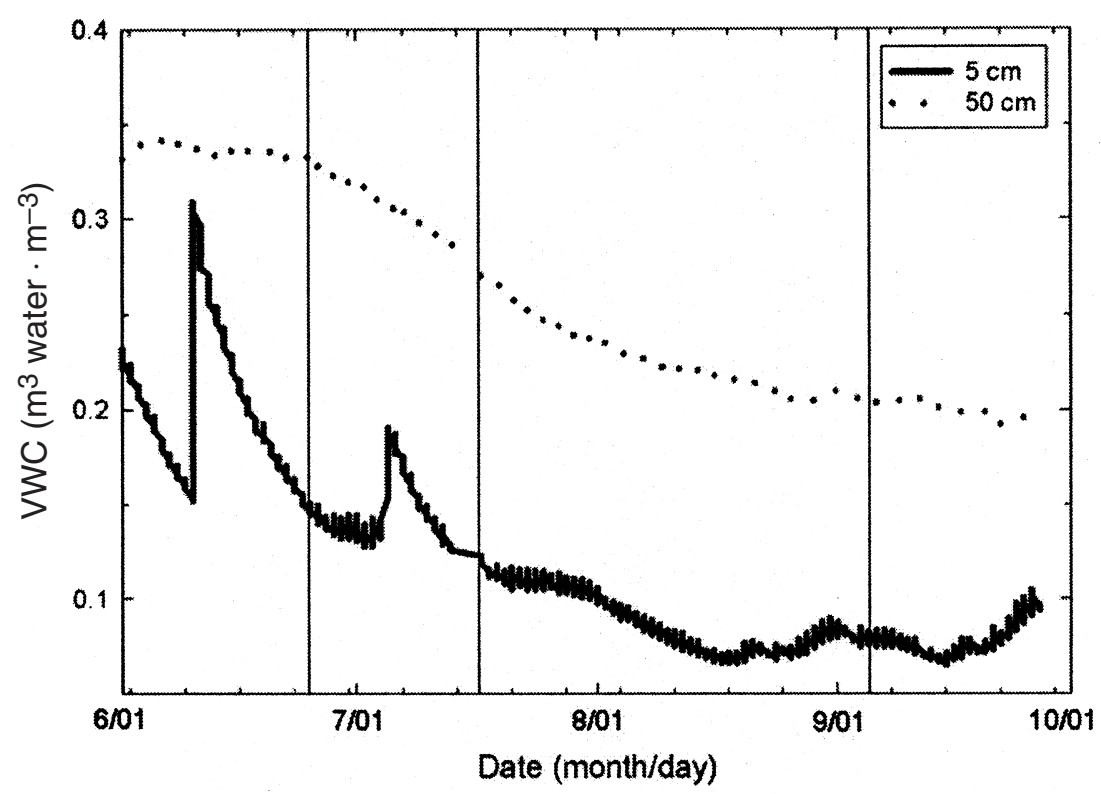

Fig. 4. Volumetric soil water content from 1 June 2004 through 30 September 2004 at $5 \mathrm{~cm}$ and $50 \mathrm{~cm}$ depth. Data are plotted as recorded in 4-hour intervals. Minor ticks on the x-axis represent 7-day intervals. Vertical lines indicate dates on which seedling physiology was measured. Two sensors were at each sampling depth.

24-25 June, $12 \%$ on 17-18 July, and $8 \%$ on 4-5 September, which were days when physiology was measured (Fig. 4). VWC was relatively higher at $50 \mathrm{~cm}$ depth, but also decreased from June $(33.4 \% \pm 0.6 \%)$ to September $(20.1 \%$ $\pm 0.5 \%$; Fig. 4 ).

For all months combined, $A_{n e t}\left(r^{2}=0.61, P\right.$ $<0.0001)$ and $g_{s}\left(r^{2}=0.80, P<0.0001\right)$ increased considerably with PDXPP (Fig. 5). Maximum levels of $A_{n e t}$ and $g_{s}$ occurred when PDXPPs were above about $-0.5 \mathrm{MPa}$ (Fig. 5). As PDXPP decreased below about $-0.5 \mathrm{MPa}$ in the latter and drier sampling dates, $A_{\text {net }}$ decreased less than the exponential decrease observed in $g_{s}$. These different responses of $A_{n e t}$ and $g_{s}$ to the seasonal drying trend led to progressive increases in water use efficiency $\left(A \cdot g_{s}^{-1}\right)$.

\section{Discussion}

Seedlings of A. tridentata ssp. vaseyana had less dry mass at the end of their 1st growth season in microsites closest to neighboring herbs. Carbon assimilation $\left(A_{n e t}\right)$ was also lower for seedlings nearer to herbs, but in June only and not in subsequent drier months. Relationships of A. tridentata ssp. vaseyana seedlings and neighboring herbs may result largely from their interactions in early summer, before the onset of seasonal water limitations to growth and when a significant amount of yearly carbon gain likely occurs for seedlings (Fig. 2). Decreases in seedling sensitivity to herbs after June could partly reflect progressive increases in spacing between them in months following June. We did not determine the precise causes of plant spacing (e.g., with repeated observations), and we speculate that increases in plant spacing during summer could have resulted from mortality of $A$. tridentata ssp. vaseyana seedlings near herbs or from senescence of herbs. Regardless of their causes, increases in neighborhood spacing could not completely explain decreases in sensitivity of seedling photosynthesis to proximity of neighboring herbs at mid- or late-summer, because there was still substantial overlap of sum distance values among all sampling dates (i.e., values $>15 \mathrm{~cm}$; Fig. 2). Thus, seedling responses to proximity of neighboring herbs likely reflect limitations to growth processes in microsites adjacent to herbs. Photosynthetic carbohydrate production is one of the primary determinants of growth rates, but we need to exercise caution when inferring how changes in photosynthesis might affect growth near herbs, because 


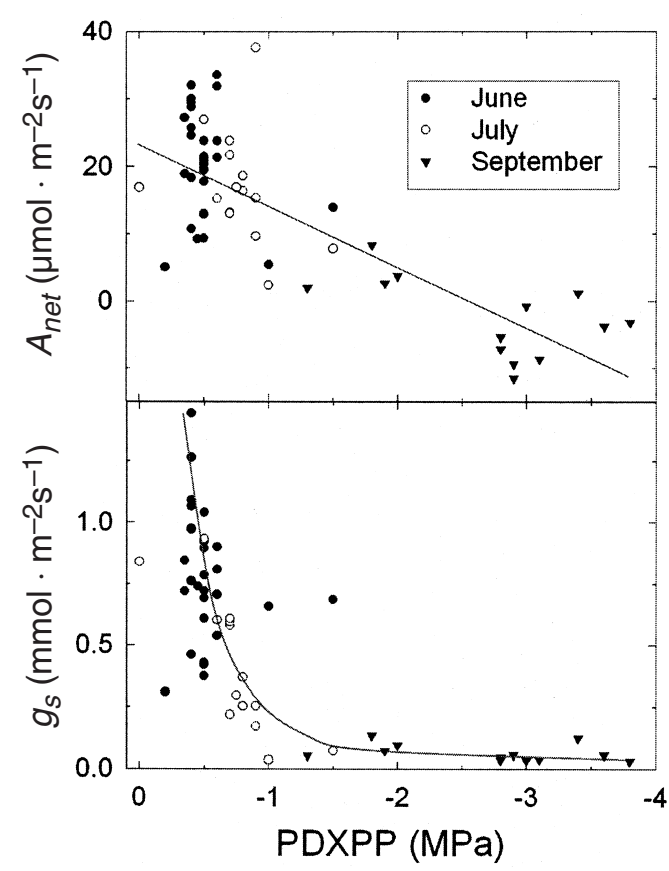

Fig. 5. Relationship of predawn xylem pressure potential (PDXPP) to photosynthesis ( $A_{\text {net }}$, top), and stomatal conductance ( $g_{s}$, bottom) of Artemisia tridentata ssp. vaseyana seedlings in 2004. Each point is a replicate seedling. The correlation of $A_{\text {net }}$ with PDXPP is significant $\left(r^{2}=0.61, P<0.0001\right)$, as is $g_{s}$ with PDXPP $\left(r^{2}=\right.$ $0.80, P<0.0001)$.

dry mass and photosynthesis were measured on different seedlings and in different years.

Decreases in photosynthesis (when normalized for area and time) result from either decreases in diffusive supply of $\mathrm{CO}_{2}$ through stomata into leaves or from reductions in the physiological demand for $\mathrm{CO}_{2}$ in carboxylation reactions (i.e., biochemical capacity to use $\mathrm{CO}_{2}$ inside leaves for carbohydrate production). Plants commonly close stomata (reduce $g_{s}$ ) to conserve water at the expense of a less diffusive supply of $\mathrm{CO}_{2}$ for carboxylation in photosynthesis (Smith et al. 1997). Reductions in $g_{s}$ can decrease $A_{n e t}$ if $\mathrm{CO}_{2}$ within leaves becomes scarce. If lower $A_{\text {net }}$ in seedlings near herbs were due to competition for water, we would have expected to observe lower water status and corresponding reductions in $g_{s}$ compared to seedlings with greater distances to herbs. Plant water status and $g_{s}$ were not correlated with proximity of neighboring herbs on any sampling date and were therefore un- likely explanations for lower $A_{\text {net }}$ in seedlings nearest to herbs. Although water availability strongly affected growth and photosynthesis (Figs. 1, 3, 5), lower $A_{\text {net }}$ and growth of A. tridentata ssp. vaseyana in microsites closest to neighboring herbs were therefore not likely to have resulted from preemption of soil water for seedlings by neighboring herbs. Additional support for excluding the direct role of water in seedling responses to herbs comes from experimental water additions; if herbs preempted water for seedlings as we hypothesized, supplemental watering would have alleviated negative relationships of seedling mass and proximity to herbs. We observed the opposite outcome.

Alternative explanations for reduced $A_{n e t}$ in A. tridentata ssp. vaseyana seedlings near herbs could include factors that affect photosynthetic demand for $\mathrm{CO}_{2}$, such as less sunlight or soil nutrient availability in microsites closer to herbs. Whereas sunlight provides the energy for reducing $\mathrm{CO}_{2}$ into carbohydrates, enzymes used in carboxylation require a substantial proportion of plant nitrogen (Lambers et al. 1998). Seedlings we studied were only rarely overtopped by neighboring herbs and often did not appear to be located closely enough to herbs to be shaded by them. Moreover, DiCristina et al. (in review) found that distances of $A$. tridentata ssp. vaseyana seedlings to neighboring herbs in sites burned 1-8 years prior to sampling were not affected by whether seedlings were located on the north or south sides of herbs; this outcome did not indicate shading effects.

High nutrient levels commonly occur after fires and could diminish the role of nutrients in plant interactions. However, nitrogen levels returned to pre-fire levels after about 10 months following fire in sagebrush (Hobbs and Schimel 1984), leading us to speculate that nutrient availability was not unusually high during the years of our study. Several studies indicated greater nutrient uptake by plants during moisture pulses in semiarid communities (Cui and Caldwell 1997, Ivans et al. 2003). Elevated rates of nutrient uptake and corresponding depletion of soil nutrients near herbs during periods of relatively high growth rate (i.e., June) would be consistent with the sensitivity of seedlings to herbs in June but not in later summer. Photosynthesis in other subspecies of sagebrush (A. tridentata 
ssp. wyomingensis) was highly responsive to manipulations of nitrogen availability (Doescher et al. 1990). Our study was not designed to experimentally isolate the importance of nutrients on $A_{\text {net }}$ of seedlings, but we speculate that nutrient limitations could be an important factor contributing to lower $A_{\text {net }}$ and growth of A. tridentata ssp. vaseyana seedlings located near herbs.

Although water did not appear to mediate seedling responses to neighboring herbs, water availability did appear to positively modulate the sensitivity of seedlings to herbs. The intensity of plant interactions in communities with low water availability and productivity is expected to be greatest during brief periods of increased resource availability, rather than periods when resource scarcity leads to reductions in background growth levels (Goldberg and Novoplansky 1997, see also Bilbrough and Caldwell 1997). The sensitivity of seedlings to neighboring herbs (Fig. 2) corresponded with strong reductions in seedling carbon uptake as soil water deficits increased during summer (Figs. 3, 5). Soil water availability is typically greatest in sagebrush steppe during spring and early summer, following snowmelt and spring rain (Fig. 4). Seedling responses to this seasonal drying were reflected in decreases in $g_{s}$ to minimum values in seedlings as (1) predawn water potentials of seedlings decreased to $\leq-1.5 \mathrm{MPa}$ and (2) volume water content decreased below $10 \%-12 \%$ and $-1.5 \mathrm{MPa}$ in soils around our TDR probes (Figs. 3-5; MPa estimate based on water retention curves; Germino and Seefeldt unpublished data). Water potentials near $-1.5 \mathrm{MPa}$ are typical thresholds for water uptake in many plant species (Lambers et al. 1998; though desert plants can have lower threshholds). Significant water consumption ceased at 10\%-12\% VWC in a related sagebrush subspecies adapted to drier conditions than A. tridentata ssp. vasey$a n a$, in a site near ours with similar soil textures (A. tridentata ssp. wyomingensis; Anderson et al. 1987, Smith et al. 1997). The possible effect of seasonal onset of drought-induced growth limitations on the progressive decrease in sensitivity of A. tridentata ssp. vaseyana seedlings to herbs (Fig. 2) is further supported by the less negative responses of seedling mass to drier soils in unwatered compared to watersupplemented treatments (Fig. 1). Supplemen- tal watering intensified the negative relationship of seedling mass and proximity to herbs. Our finding of greater negative responses of A. tridentata ssp. vaseyana seedlings to neighboring herbs when soil resources and growth processes were at seasonal maximums matches the prediction that the intensity of plant interactions in arid environments is greatest when growth resources are most abundant.

\section{Summary and Implications}

Dry mass gain and early season photosynthesis in A. tridentata ssp. vaseyana establishing following fire was negatively correlated with proximity to neighboring herbs. Nearly inverse relationships of A. tridentata ssp. vaseyana establishment and herb cover during disturbance-succession cycles, and much larger distances of A. tridentata ssp. vaseyana seedlings to neighboring herbs after fire than could occur randomly (DiCristina et al. in review), may therefore be partly attributable to physiological responses of A. tridentata ssp. vaseyana to herbs. Contrary to our predictions, negative responses of seedlings to neighboring herbs did not appear attributable to interactions over water availability, but more likely resulted from interactions over factors such as nutrients. Although water did not have a direct role in mediating sagebrush seedling relationships with neighboring herbs, water availability indirectly affected the relationships by influencing the intensity of seedling responses to herbs.

The herbaceous flora of sagebrush steppe is changing rapidly due to exotic plant invasions, selective use of species in plantings, and management activities. Determining how herbaceous species differ in their effects on young sagebrush seedlings is an important research need, particularly in light of changes in precipitation and other aspects of environmental change.

\section{ACKNOWLEDGMENTS}

Research funding was provided by the U.S. National Aeronautics and Space Administration to K. Weber, N. Glenn, and M. Germino. Steve Seefeldt provided commentary and access to study sites.

\section{Literature Cited}

Anderson, J.E., M.L. Shumar, N.L. Toft, and R.S. NOWAK. 1987. Control of the soil water balance by 
sagebrush and three perennial grasses in a colddesert environment. Arid Soil Research and Rehabilitation 1:229-244.

Berlow E.L., C.M. D’Antonio, and S.A. Reynolds. 2002. Shrub expansion in montane meadows: the interaction of local-scale disturbance and site aridity. Ecological Applications 12:1103-1118.

Bilbrough, C.J., and M.M. Caldwell.1997. Exploitation of springtime ephemeral N pulses by six Great Basin plant species. Ecology 78:231-243.

Brooks, M.L., AND D.A. PYKe. 2001. Invasive plants and fire in the deserts of North America. Pages 1-14 in K.E.M Galley and T.P. Wilson, editors, Proceedings of the invasive species workshop: the role of fire in the control and spread of invasive species. Fire Conference 2000: the First National Congress on Fire Ecology, Prevention, and Management. Tall Timbers Research Station, Tallahassee, FL.

Chambers, J. 2000. Seed movements and seedling fates in disturbed sagebrush steppe ecosystems: implications for restoration. Ecological Applications 10:1400-1413.

Connelly, J.W., K.P. Reese, R.A. Fischer, and W.L. WAKKINEN. 2000. Response of a sage grouse breeding population to fire in southeastern Idaho. Wildlife Society Bulletin 28:90-96.

CoOK, C.W., AND C.E. LewIS. 1963. Competition between big sagebrush and seeded grasses on foothill ranges in Utah. Journal of Range Management 16:245-250.

Cui, M., AND M.M. Caldwell. 1997. A large ephemeral release of nitrogen upon wetting of dry soil and corresponding root responses in the field. Plant and Soil 191:291-299.

DaubenmiRe, R.F. 1975. Ecology of Artemisia tridentata subsp. tridentata in the state of Washington. Northwest Science 49:24-35.

Doscher, P.S., R.F. Miller, J. Wang, and J. Rose. 1990. Effects of nitrogen availability on growth and photosynthesis of Artemisia tridentata ssp. wyomingensis. Great Basin Naturalist 50:9-19.

Goldberg, D.E., AND A. Novoplansky. 1997. On the relative importance of competition in unproductive environments. Journal of Ecology 85:409-418.

Harniss, R.O., AND R.B. Murray. 1973. 30 years of vegetal change following burning of sagebrush-grass range. Journal of Range Management 26:322-325.

HobBS, N.T., AND D.S. SchimeL. 1984. Fire effects on nitrogen mineralization and fixation in mountain shrub and grassland communities. Journal of Range Management 37:402-405.
Ivans, C.Y., A.J. Leffler, U. Spaulding, J.M. Stark, R.J. Ryel, AND M.M. Caldwell. 2003. Root responses and nitrogen acquisition by Artemisia tridentata and Agropyron desetorum following small summer rainfall events. Oecologia 234:17-324.

Lambers, H., F.S. Chapin, III, And T.L. Pons. 1998. Plant physiological ecology. Springer, New York.

Natural Resources Conservation Service. 1995. Soil investigation of Agriculture Research Service, United States Sheep Experiment Station headquarters range. United States Department of Agriculture, Natural Resource Conservation Service, Rexburg, ID.

Owens, M.K., AND B.E. NorTon. 1989. The impact of available area on Artemisia tridentata seedling dynamics. Vegetatio 82:155-162.

Schuman, G.E., D.T. Booth, and J.R. Cockrell. 1998. Cultural methods for establishing Wyoming big sagebrush on mined lands. Journal of Range Management 51:223-230.

Smith, S.D., Monson, R.K., And J.E. Anderson. 1997. Physiological ecology of North American desert plants. Springer, Berlin.

Smith, W.K., A.W. Schoettle, AND M. Cui, 1991. Importance of the method of leaf area measurement to the interpretation of gas exchange of complex shoots. American Journal of Botany 75:496-500.

Tyler, C.M. 1996. Relative importance of factors contributing to postfire seedling establishment in maritime chaparral. Ecology 77:2182-2195.

Wambolt, C.L., K.S. Walhof, and M.R. Frisina. 2001. Recovery of big sagebrush communities after burning in southwestern Montana. Journal of Environmental Management 61:243-252.

WEst, N.E., AND M.A. Hassan. 1985. Recovery of sagebrush-grass vegetation following wildfire. Journal of Range Management 38:131-134.

Young, J.A., AND R.A. Evans. 1978. Population dynamics after wildfires in sagebrush grasslands. Journal of Range Management 31:283-289.

Young, J.A., R.A. Evans, And D.E. PalmQuist. 1990. Soil surface characteristics and emergence of big sagebrush seedlings. Journal of Range Management 43: 358-367.

Received 5 November 2005 Accepted 24 April 2006 